\title{
A Conjugated Linoleic Acid Supplement Containing Trans-10, Cis-12 Conjugated Linoleic Acid Reduces Milk Fat Synthesis in Lactating Goats ${ }^{1}$
}

\author{
A. L. Lock, ${ }^{*}$ M. Rovai, $†$ T. A. Gipson, $†$ M. J. de Veth, $\neq^{2}$ and D. E. Bauman $\S^{3}$ \\ *Department of Animal Science, University of Vermont, Burlington 05405 \\ †E (Kika) de la Garza American Institute for Goat Research, Langston University, Langston, OK 73050 \\ ‡BASF AG, Nutrition Research Station, Neumuehle 13, 76877, Offenbach/Queich, Germany \\ §Department of Animal Science, Cornell University, Ithaca, NY 14853
}

\begin{abstract}
The effect of conjugated linoleic acid (CLA) supplements containing trans-10, cis-12 for reducing milk fat synthesis has been well described in dairy cows and sheep. Studies on lactating goats, however, remain inconclusive. Therefore, the current study investigated the efficacy of a lipid-encapsulated trans-10, cis-12 CLA supplement (LE-CLA) on milk production and milk fatty acid profile in dairy goats. Thirty multiparous Alpine lactating goats in late lactation were used in a 3 $\times 3$ Latin square design (14-d treatment periods separated by 14-d intervals). Does were fed a total mixed ration of Bermuda grass hay, dehydrated alfalfa pellets, and concentrate. Does were randomly allocated to 3 treatments: A) unsupplemented (control), B) supplemented with $30 \mathrm{~g} / \mathrm{d}$ of LE-CLA (low dose; CLA-1), and C) supplemented with $60 \mathrm{~g} / \mathrm{d}$ of LE-CLA (high dose; CLA-2). Milk yield, dry matter intake, and milk protein content and yield were unaffected by treatment. Compared with the control, milk fat yield was reduced $8 \%$ by the CLA -1 treatment and $21 \%$ by the CLA- 2 treatment, with milk fat content reduced 5 and $18 \%$ by the CLA- 1 and CLA-2 treatments, respectively. The reduction in milk fat yield was due to decreases in both de novo fatty acid synthesis and uptake of preformed fatty acids. Milk fat content of trans-10, cis-12 CLA was $0.03,0.09$, and $0.19 \mathrm{~g} / 100 \mathrm{~g}$ of fatty acids for the control, CLA-1, and CLA-2 treatments, respectively. The transfer efficiency of trans-10, cis-12 CLA from the 2 levels of CLA supplement into milk fat was not

\footnotetext{
Received February 1, 2008.

Accepted May 9, 2008.

${ }^{1}$ Supported in part by E (Kika) de la Garza American Institute

${ }^{2}$ Present address: Balchem Corporation, New Hampton, NY
} for Goat Research, University of Vermont Agricultural Experiment Station, Cornell University Agricultural Experiment Station, and the National Research Initiative Competitive Grants Program, Cooperative State Research, Education, and Extension Service, USDA (grant \#2006-35206-16643). 10958.

${ }^{3}$ Corresponding author: deb6@cornell.edu
\end{abstract}

different between treatments and averaged $1.85 \%$. In conclusion, trans-10, cis-12 CLA reduced milk fat synthesis in lactating dairy goats in a manner similar to that observed for lactating dairy cows and dairy sheep. Dose-response comparisons, however, suggest that the degree of reduction in milk fat synthesis is less in dairy goats compared with dairy cows and dairy sheep.

Key words: conjugated linoleic acid, milk fat depression, goat, lactation

\section{INTRODUCTION}

Trans-10, cis-12 conjugated linoleic acid (CLA) is an intermediate produced in the biohydrogenation of linoleic acid by rumen bacteria (Bauman and Griinari, 2003). As reviewed by Bauman et al. (2008), this bioactive fatty acid is associated with diet-induced milk fat depression, and its role in the regulation of milk fat synthesis has been extensively characterized in dairy cows. Formulations of CLA that offer some protection against rumen biohydrogenation have been developed and used as management tools to examine the controlled reduction in milk fat during situations in which dietary energy intake may be inadequate to meet nutrient requirements (Griinari and Bauman, 2006).

Trans-10, cis-12 CLA has also been found to reduce milk fat yield or content, or both, in other lactating nonruminant and ruminant species in addition to the dairy cow (Bauman et al., 2008). In lactating sheep, administration of a supplement containing trans-10, cis-12 CLA decreases milk fat production, with the magnitude of the reduction being similar to dairy cows when the dose is expressed on a metabolic BW basis or when compared on the basis of the trans-10, cis-12 content of milk fat (Lock et al., 2006; Sinclair et al., 2007; Weerasinghe et al., 2007). In contrast, recent investigations involving goats reported that trans-10, cis-12 CLA had little or no effect on milk fat yield (Erasmus et al., 2004; Schmidely and Morand-Fehr, 2004; de Andrade and Schmidely, 2006). These findings contrast from the consistent effects of CLA on decreas- 
ing milk fat production observed with cows and sheep, and may be a result of species differences and the fact that the goat may be unresponsive or less sensitive to trans-10, cis-12 CLA (Sanz Sampelayo et al., 2007). Alternatively, it may be a consequence of experimental design or study differences in the aforementioned goat investigations, or both.

Our objective was to determine if a lipid-encapsulated supplement containing trans-10, cis-12 CLA would inhibit milk fat synthesis in lactating goats. We based our approach on published studies with cows and sheep in terms of CLA dose, duration of treatment, and experimental design. A secondary objective was to examine the effects of trans-10, cis-12 CLA on milk fatty acid composition and transfer of this CLA isomer to milk fat. In some cow and sheep studies, the CLA-induced reduction in milk fat has been associated with an increase in milk yield and milk protein yield, although this appears to coincide with situations when energy or protein was limiting (Griinari and Bauman, 2006); thus, responses in these variables were also of interest.

\section{MATERIALS AND METHODS}

\section{Animals and Experimental Design}

The experiment was conducted under the approval of Langston University's Institutional Animal Use and Care Committee. Thirty multiparous, nonpregnant Alpine dairy goats in late lactation $(145 \pm 36 \mathrm{DIM})$ were used from the E (Kika) de la Garza American Institute for Goat Research (Langston University). Goats were housed indoors and offered fresh feed once daily at $0800 \mathrm{~h}$. Diet was provided as a TMR, and major dietary components included Bermuda grass hay, alfalfa pellets, and a concentrate mixture (Table 1). The diet was initially offered at approximately $3 \mathrm{~kg} / \mathrm{d}$, (DMI represented $\sim 3.5 \%$ of BW) and was then adjusted daily to allow for an ad libitum intake. Daily feed intakes were recorded using the Calan headgate system (American Calan Inc., Northwood, NH). In addition, salt blocks (American Stockman, North American Salt Co., Overland Park, KS) and fresh water were available ad libitum.

Does were milked twice daily at 0430 and $1600 \mathrm{~h}$, and milk yield was recorded at each milking throughout the experimental period by the automated Westfalia milking system (Westfalia Systemat, Elk Grove Village, IL). The regular milking routine included teat cleaning, automatic take-off of milking units, and teat dipping. At the start of the experiment, goats were free from clinical mastitis, and milk production averaged $2.87 \pm 0.21 \mathrm{~kg} / \mathrm{d}($ mean $\pm \mathrm{SE})$.
Table 1. Ingredient and chemical composition of the experimental diet

\begin{tabular}{lc}
\hline Composition $^{1}$ & TMR \\
\hline Ingredient, \% & \\
Alfalfa pellets & 19.69 \\
Bermuda grass & 19.93 \\
Corn & 22.16 \\
Wheat middlings & 17.01 \\
Soybean meal & 9.81 \\
Liquid molasses & 5.91 \\
Megalac & 2.69 \\
Sodium bicarbonate & 0.90 \\
Limestone & 0.86 \\
Vitamin A, D, E premix ${ }^{3}$ & 0.49 \\
Trace mineral salt premix & \\
Magnesium oxide & 0.45 \\
Chemical analysis & 0.10 \\
DM, \% & \\
CP, \% of DM & 90.2 \\
NDF, \% of DM & 11.4 \\
ADF, \% of DM & 35.4 \\
NE & Mcal/kg of DM \\
\hline
\end{tabular}

${ }^{1}$ Ingredient and chemical composition do not include the lipid-encapsulated conjugated linoleic acid supplement.

${ }^{2}$ Calcium soap of palm oil fatty acids (Church \& Dwight Co. Inc., Princeton, NJ). Fatty acid composition, as reported by the company, is $1.2 \% 12: 0+14: 0,48 \% 16: 0,5 \% 18: 0,36 \%$ cis-9 $18: 1$, and $9 \% 18: 2$.

${ }^{3}$ The vitamin premix contained the following per gram: 8,800 IU of vitamin $\mathrm{A}, 1,760 \mathrm{IU}$ of vitamin $\mathrm{D}_{3}$, and $1.1 \mathrm{IU}$ of vitamin $\mathrm{E}$.

${ }^{4}$ The traced mineralized salt contained the following: 96 to $99 \% \mathrm{NaCl}$ and at least $0.24 \% \mathrm{Mn}, 0.24 \% \mathrm{Fe}, 0.05 \% \mathrm{Mg}, 0.032 \% \mathrm{Cu}, 0.011 \% \mathrm{Co}$, $0.004 \% \mathrm{I}$, and $0.032 \% \mathrm{Zn}$.

The experimental design was a $3 \times 3$ Latin square with 14-d treatment periods separated by 14 -d washout intervals. The CLA supplement was a lipid-encapsulated formulation (LE-CLA; marketed as Lutrell by BASF AG, Ludwigshafen, Germany) comprised of 2 CLA isomers in equal proportions: cis-9, trans-11 and trans-10, cis-12 CLA. Dietary treatments were as follows: A) unsupplemented (control), B) supplemented with $30 \mathrm{~g} / \mathrm{d}$ of LE-CLA (low dose; CLA-1), or C) supplemented with $60 \mathrm{~g} / \mathrm{d}$ of LE-CLA (high dose; CLA-2). The LE-CLA supplement had a lipid content of $65 \%$ and a fatty acid composition of $15 \%$ trans-10, cis-12 CLA; $15 \%$ cis-9, trans-11 CLA; 9\% 16:0; 42\% 18:0; 12\% cis-9 18:1; and $1 \%$ cis-9, cis-12 18:2. Thus, the CLA-1 and CLA-2 treatments provided trans-10, cis-12 CLA at a rate of 3 and $6 \mathrm{~g} / \mathrm{d}$, respectively. The LE-CLA supplement was mixed with dry molasses on a daily basis and given before feeding to assure it was consumed totally.

Goats averaged $50 \pm 7.4 \mathrm{~kg}$ of BW and 2.5 BCS (1 to 5 scale by 0.5 increments; Villaquiran et al., 2005) at the start of the study. They were weighed, and condition was scored at the beginning and end of each 14-d treatment period. Milk was sampled at each milking and analyzed for fat, protein, lactose, solids, and SCC using a CombiFoss 5000 (Foss Food Technology, Eden Prairie, MN) at Langston University DHI Laboratory. 
Table 2. Performance of lactating goats supplemented with lipid-encapsulated conjugated linoleic acid $(\mathrm{CLA})^{1}$

\begin{tabular}{|c|c|c|c|c|c|}
\hline \multirow[b]{2}{*}{ Variable } & \multicolumn{3}{|c|}{ Treatment $^{2}$} & \multirow[b]{2}{*}{ SEM } & \multirow[b]{2}{*}{$P$-value } \\
\hline & Control & CLA-1 & CLA-2 & & \\
\hline DMI, kg/d & 2.57 & 2.54 & 2.48 & 0.11 & 0.48 \\
\hline Milk yield, g/d & 2,673 & 2,641 & 2,621 & 85 & 0.84 \\
\hline \multicolumn{6}{|l|}{ Milk fat } \\
\hline$\%$ & $3.12^{\mathrm{a}}$ & $2.97^{\mathrm{b}}$ & $2.57^{\mathrm{c}}$ & 0.07 & $<0.001$ \\
\hline $\mathrm{g} / \mathrm{d}$ & $85.1^{\mathrm{a}}$ & $78.2^{\mathrm{b}}$ & $67.1^{\mathrm{c}}$ & 3.5 & $<0.001$ \\
\hline \multicolumn{6}{|l|}{ Milk protein } \\
\hline$\%$ & 2.51 & 2.50 & 2.48 & 0.04 & 0.65 \\
\hline $\mathrm{g} / \mathrm{d}$ & 66.1 & 65.8 & 65.2 & 2.2 & 0.75 \\
\hline \multicolumn{6}{|l|}{ Milk lactose } \\
\hline$\%$ & $4.09^{\mathrm{a}}$ & $4.09^{\mathrm{a}}$ & $4.03^{\mathrm{b}}$ & 0.03 & $<0.05$ \\
\hline $\mathrm{g} / \mathrm{d}$ & 109.8 & 108.0 & 105.8 & 3.6 & 0.56 \\
\hline
\end{tabular}

On the final day of each treatment period, additional milk samples were collected and stored at $-20^{\circ} \mathrm{C}$ until subsequent fatty acid analysis.

\section{Chemical Analysis}

Feed samples were collected twice during each treatment period. Composites were formed and analyzed according to AOAC (2000) wet chemistry procedures by Dairy One Cooperative Inc. (Ithaca, NY) with values reported for $\mathrm{CP}, \mathrm{ADF}, \mathrm{NDF}$, and $\mathrm{NE}_{\mathrm{L}}$.

For analysis of milk fatty acids, the a.m. and p.m. milk samples from the last day of each treatment period were composited based on volume, and fat was extracted using the method of Hara and Radin (1978). Fatty acid methyl esters were prepared by base-catalyzed transmethylation according to Christie (1982) with modifications by Chouinard et al. (1999). Fatty acid methyl esters were quantified using a gas chromatograph (GC system 6890+ with flame-ionization detector; Agilent Inc., Wilmington, DE) equipped with a CP-SIL 88 fused-silica capillary column [100 $\mathrm{m} \times$ $0.25 \mathrm{~mm}$ (i.d.) with $0.2-\mu \mathrm{m}$ film thickness; Varian Inc., Walnut Creek, CA] as described previously (Lock et al., 2006). Fatty acid identification and recoveries were determined using pure methyl ester standards (Nu-Chek Prep, Elysian, MN; Natural ASA, Hovdebygda, Norway) along with comparisons of the elution order for trans-18:1 isomers reported in the literature. A butter oil reference standard (CRM 164; Commission of the European Community Bureau of References, Brussels, Belgium) was used as a routine quality control and as a check for recoveries and correction factors for individual fatty acids.
The LE-CLA supplement was analyzed for lipids following the extraction and methylation procedures described by Perfield et al. (2004). Analysis of fatty acid methyl esters was as detailed above for milk fatty acids.

\section{Statistical Analysis}

Milk production and DMI data for the final $4 \mathrm{~d}$ of each treatment period were averaged. Intake, milk production and composition, BW, BCS, and milk fatty acid composition were analyzed as a $3 \times 3$ Latin square design using JMP (Version 5, SAS Institute, Cary, NC). The mixed model to test treatment means included the random effect of goat and fixed effect of period and treatment, and results are presented as treatment means with a SEM. Treatment effects were considered significant at $P<0.05$.

\section{RESULTS}

Performance data are summarized in Table 2. The DMI did not differ among treatment groups and averaged $2.5 \pm 0.1 \mathrm{~kg} / \mathrm{d}$ (mean $\pm \mathrm{SE}$ ) for $\mathrm{d} 11$ to 14 of the treatment period (Table 2). Similarly, BW and BCS were not affected by the treatments and averaged 50.5 $\pm 1.4 \mathrm{~kg}$ and $2.2 \pm 0.1$ (mean $\pm \mathrm{SE}$ ), respectively, for the experimental periods (data not presented).

Milk yield and milk protein content and yield were unaffected by treatments (Table 2). Similarly, milk lactose yield did not differ among treatments, although milk lactose content was slightly lower $(\sim 1 \%)$ in the CLA-2 treatment as compared with control and CLA1 treatments (Table 2). Examination of the temporal 

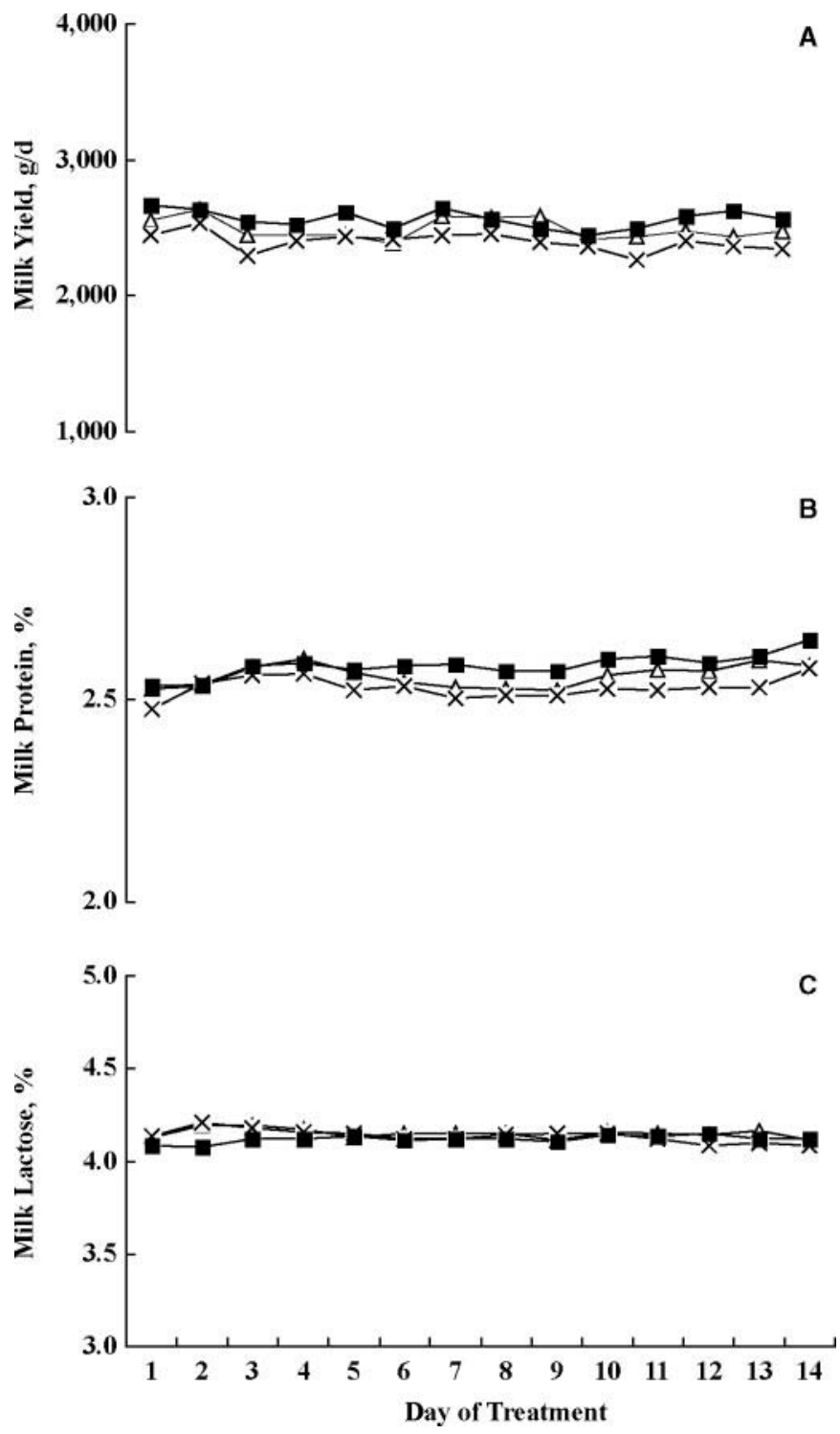

Figure 1. Temporal pattern of (A) milk yield, (B) milk protein percentage, and $(\mathrm{C})$ milk lactose percentage of lactating goats un-

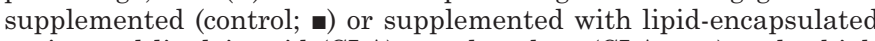
conjugated linoleic acid (CLA) at a low dose (CLA-1; $\Delta$ ) and a high dose (CLA-2; $\times$ ). Values represent means from 30 does; $\mathrm{SEM}=85 \mathrm{~g} / \mathrm{d}$, $0.04 \%$, and $0.04 \%$ for milk yield, milk protein percentage, and milk lactose percentage, respectively.

pattern indicated that milk yield and the milk content of protein and lactose were relatively constant over the treatment period (Figure 1). In contrast, the temporal pattern for milk fat content and yield demonstrated a progressive decline over the 14-d treatment period (Figure 2). Compared with control, milk fat yield by d 11 to 14 was reduced by 8 and $21 \%$ for the CLA- 1 and CLA-2 treatments, respectively. Similar values for milk fat content were a reduction of 5 and $18 \%$, respectively (Table 2).
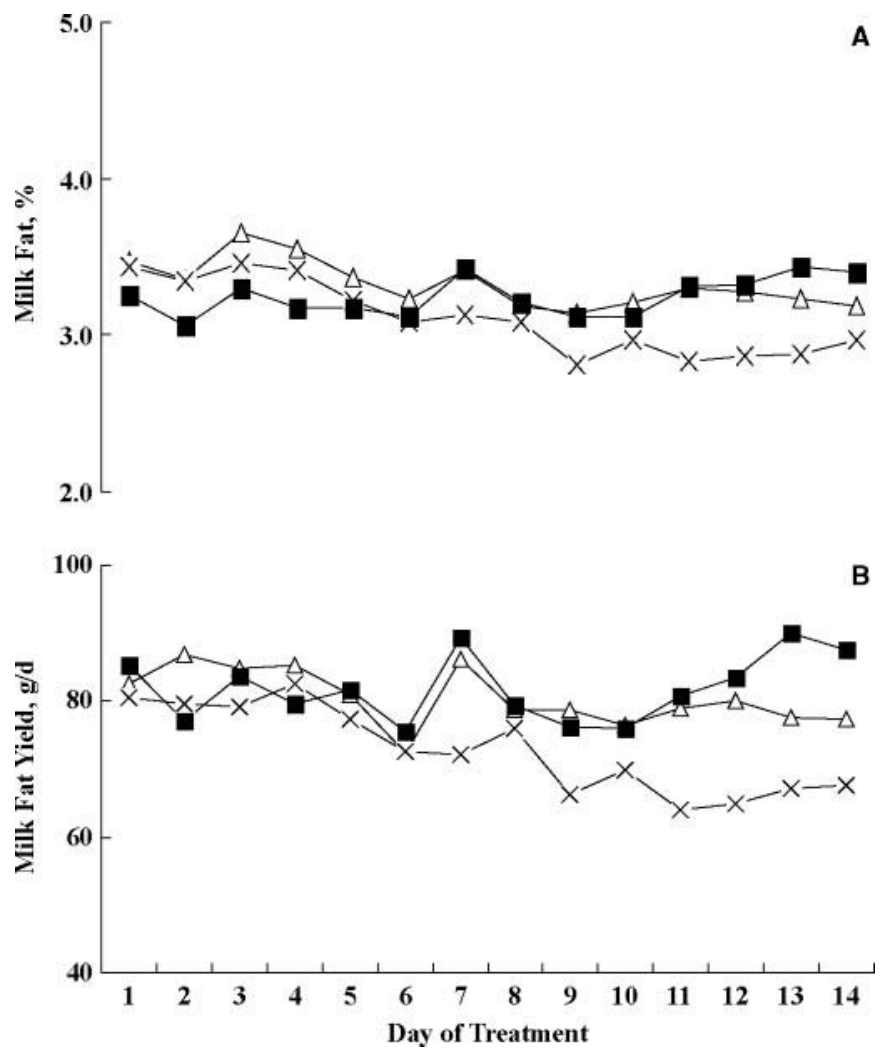

Figure 2. Temporal pattern of (A) milk fat percentage and (B) milk fat yield of lactating goats unsupplemented (control; a) or supplemented with lipid-encapsulated conjugated linoleic acid (CLA) at a low dose (CLA-1; $\Delta$ ) and a high dose (CLA-2; $\times$ ). Values represent means from 30 does; $\mathrm{SEM}=0.06 \%$ and $5.0 \mathrm{~g} / \mathrm{d}$ for milk fat percentage and milk fat yield, respectively.

Treatment with the CLA supplements altered the composition of the milk fat (Table 3). Relative to control, the greatest effects were observed for the CLA-2 treatment with numerical values for the CLA-1 treatment being intermediate. Changes in the composition included a reduction in the proportion of short- and medium-chain fatty acids (C6 to C14) and an increase in most long-chain fatty acids ( $\geq 18$ carbons). When grouped according to source (Bauman and Griinari, 2003), those fatty acids synthesized de novo by the mammary gland $(<\mathrm{C} 16)$ were decreased from $29 \%$ of the total in control treatment to $24 \%$ in the CLA-2 treatment; a reciprocal increase occurred in those fatty acids derived by mammary uptake from circulation $(>\mathrm{C} 16)$. Palmitic acid and palmitoleic acid came from both sources and were modestly increased in the milk fat of LE-CLA-supplemented goats (Table 3).

Several pairs of fatty acids in milk fat represent a substrate-product relationship for the mammary enzyme $\Delta^{9}$-desaturase, also known as stearoyl coenzyme A desaturase. Using the procedure of Kelsey et 
al. (2003), we calculated the desaturase index based on these fatty acid pairs, and results are presented in Table 3. Relative to the control treatment, the high dose of CLA resulted in a significant reduction in the desaturase index with intermediate values for the CLA-1 treatment.

Examination of the effects of LE-CLA supplements on the secretion of fatty acids (molar basis) demonstrated that the CLA treatments resulted in a decrease in the secretion of milk fatty acids arising from both de novo synthesis and direct uptake from circulation (Figure 3). Effects on de novo synthesis, however, were more pronounced, and this is the basis for the observed increase in the proportion of long-chain fatty acids in milk fat when goats received LE-CLA supplements (Table 3).

The LE-CLA supplements provided cis-9, trans-11 CLA and trans-10, cis-12 CLA, and the milk fat content of both of these CLA isomers was increased (Table 3). Trans-10, cis-12 CLA was of particular interest because of its inhibitory effects on milk fat synthesis, and its content in milk fat increased from $0.03 \mathrm{~g} / 100 \mathrm{~g}$ of fatty acids in the control treatment to 0.09 and 0.19 $\mathrm{g} / 100 \mathrm{~g}$ of fatty acids for the CLA-1 and CLA-2 treatments, respectively. Transfer efficiencies for trans-10, cis-12 CLA into milk fat were estimated by comparing dietary intake and milk fat secretion. Correcting for values observed during the control treatment, transfer

Table 3. Fatty acid composition of milk fat from lactating goats supplemented with lipid-encapsulated conjugated linoleic acid (CLA) ${ }^{1}$

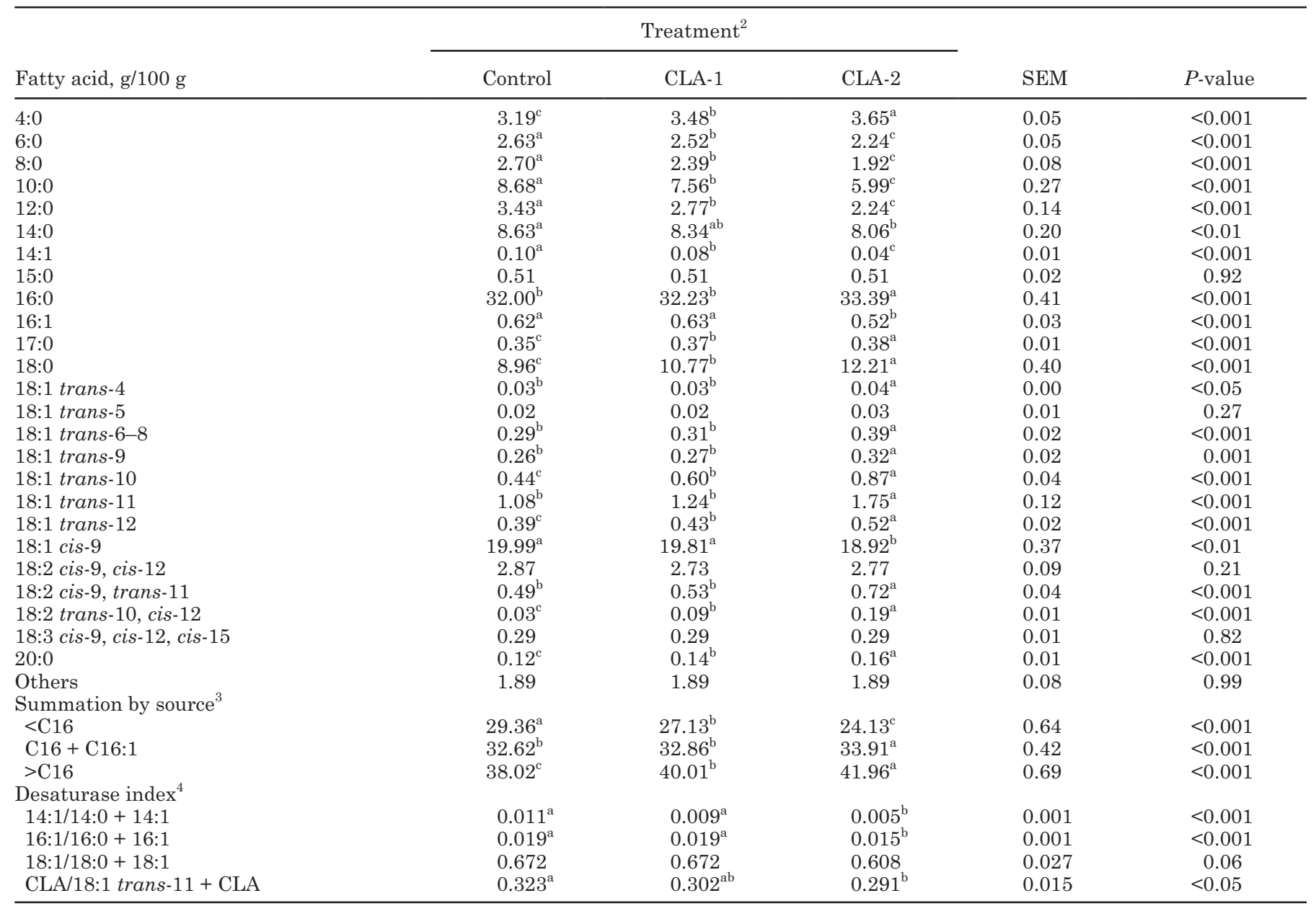

${ }^{\mathrm{a}-\mathrm{c}}$ Means within a row with different superscripts differ at $P<0.05$.

${ }^{1}$ Values represent an average of samples obtained on d 14 of supplementation. Double bonds are in the cis orientation unless otherwise indicated.

${ }^{2}$ Treatments were unsupplemented (control) or supplemented with lipid-encapsulated CLA at 30 g/d (CLA-1) or 60 g/d (CLA-2).

${ }^{3}$ Fatty acids $<$ C16 originate from de novo synthesis, fatty acids $>$ C16 are preformed fatty acids taken up by the mammary gland, and C16 and C16:1 fatty acids come from both de novo and preformed sources.

${ }^{4}$ Values represent ratio of product/(substrate + product) for $\Delta^{9}$-desaturase. 
efficiencies were similar (1.80 vs. $1.89 \% ; P=0.44)$ for the 2 CLA treatments.

\section{DISCUSSION}

The role of CLA isomers in the regulation of milk fat synthesis has been investigated most extensively in the cow (Shingfield and Griinari, 2007; Bauman et al., 2008). In particular, studies have demonstrated that trans-10, cis-12 CLA is a potent inhibitor of milk fat synthesis, and dose-response relationships have been established using abomasal infusion of relatively pure trans-10, cis-12 CLA (de Veth et al., 2004). The present study extends these observations to lactating goats and demonstrated the temporal pattern and dose relationship for the reduction in milk fat when a LE-CLA supplement was fed. The lipid-encapsulated formulation of CLA used in the present study has been used previously in studies with lactating sheep (Lock et al., 2006; Sinclair et al., 2007) and cows (de Veth et al., 2006; Castañeda-Gutiérrez et al., 2007), and is commercially used (marketed as Lutrell) throughout the European Union. The low dose of CLA was chosen as discussed by Lock et al. (2006) based on the published dose-response relationship for milk fat content of trans-10, cis-12 CLA (de Veth et al., 2004) and previous results with this CLA formulation in sheep and cows. The high dose (CLA-2 treatment) was twice the low dose to allow for comparisons of response relationships with data from other ruminant species.

The LE-CLA supplement contained 2 CLA isomers in equal proportions, trans-10, cis-12 and cis-9, trans-11. Previous studies have shown that the cis-9, trans-11 CLA isomer had no effect on milk fat synthesis in dairy cows (Baumgard et al., 2000, 2002; Loor and Herbein, 2003), and based on this, the milk fat reduction we observed in goats was due to the trans-10, cis-12 CLA in the supplement. In the present study in which goats were in late lactation, the CLA supplement had no effect on the yield of milk, milk protein, or milk lactose (Table 2). As reviewed by Griinari and Bauman (2006), similar results have generally been observed in studies with dairy cows. In some situations, however, the reduction in milk fat has resulted in a repartitioning of nutrients to support increased milk and milk protein yields in sheep (Lock et al., 2006; Weerasinghe et al., 2007) and cows (Bernal-Santos et al., 2003; Mackle et al., 2003; Odens et al., 2007); this has been most often seen in early lactation or in situations in which nutrient intake to meet requirements tends to be less than optimal.

The mechanism for the trans-10, cis-12 CLA-induced reduction in milk fat synthesis involves a coordinated reduction in the mRNA expression for key enzymes in-

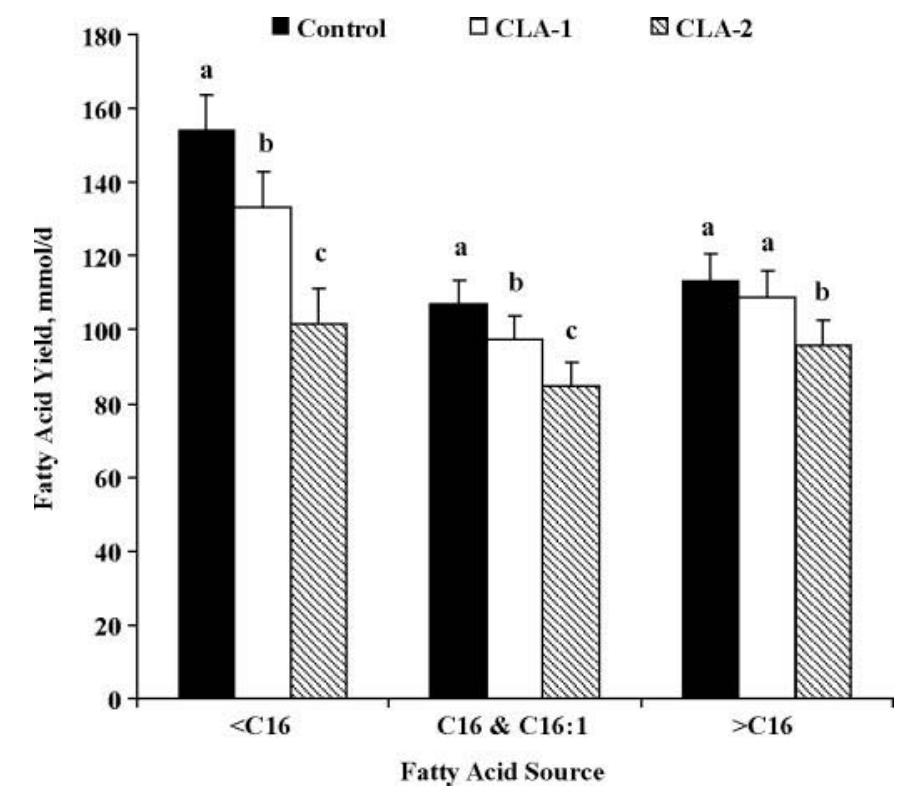

Figure 3. Milk fatty acid yield $(\mathrm{mmol} / \mathrm{d})$ in goats $(\mathrm{n}=30)$ that were unsupplemented (control; black bars) or supplemented with lipid-encapsulated conjugated linoleic acid (CLA) at a low (CLA-1; open bars) and a high dose (CLA-2; cross-hatched bars). Values for individual fatty acids were calculated using milk fat yield treatment means for d 11 to 14 and milk fatty acid composition from d 14 of treatment. Fatty acids are categorized according to origin; $<\mathrm{C} 16$ represent de novo synthesized fatty acids, $>$ C16 represent preformed fatty acids taken up from circulation, and C16 fatty acids are derived from both sources. Standard error is indicated by error bars over each column. ${ }^{a-c}$ Within each fatty acid source, treatment effects with significance differences are indicated by letters over the columns $(P$ $<0.001$ for all).

volved in milk fat synthesis (Bauman et al., 2008), and a role for sterol response element-binding protein 1 and Spot 14 has been indicated in the cellular signaling (Harvatine and Bauman, 2006). Consistent with this, investigations with cows and sheep have established that trans-10, cis-12 CLA results in a reduction in the secretion of milk fatty acids arising from both de novo synthesis and preformed uptake from the circulation, although de novo synthesis is more dramatically affected (Griinari and Bauman, 2006). A similar pattern of response in milk fatty acids occurred in the present study with lactating goats (Figure 3). Likewise, effects on milk fat desaturase indices observed with the CLA2 treatment (Table 3) were as reported previously at greater doses of trans-10, cis-12 CLA in studies with lactating cows and sheep.

The CLA-induced reduction in milk fat we observed contrasts with the lack of effect reported in 2 previous reports with lactating goats. Differences appear to relate primarily to design and duration, because these investigations involved jugular infusion of trans-10, cis-12 CLA for $2 \mathrm{~d}$ with effects compared with the day (2 milkings) immediately before the infusion (Schmidely and 
Morand-Fehr, 2004) or duodenal infusion of trans-10, cis-12 CLA for $3 \mathrm{~d}$ followed immediately by a 2 -d control infusion of skim milk (de Andrade and Schmidely, 2006). Two of the key lipogenic enzymes involved in the coordinated mechanism of the CLA-induced reduction in milk fat are acetyl coenzyme A carboxylase and fatty acid synthase, and they have a half-life of 48 to $76 \mathrm{~h}$ (Craig et al., 1972; Volpe and Vagelos, 1973). Consistent with this, the pattern of the reduction in milk fat is one of a progressive decline over the first few days of CLA treatment, and termination of CLA treatment results in a similar progressive recovery that is a mirror image of the CLA-induced decline. Thus, results in the previous goat study in which the control period immediately followed the treatment period with no interceding washout interval would be confounded, and this would be further exacerbated when the treatment period is of short duration.

Interestingly, the investigation by de Andrade and Schmidely (2006) observed that the 3-d CLA infusion increased milk fat content of trans-10, cis-12 CLA and altered desaturase indices, although milk fat yield was unaltered. The desaturase indices are a proxy for $\Delta^{9}$-desaturase, and these results are not unexpected; although studies show that changes in $\Delta^{9}$-desaturase are not a prerequisite for the CLA-induced reduction in milk fat yield (see discussion in Perfield et al., 2004), this enzyme is also coordinately regulated by CLA and has a short half-life of only 2 to $4 \mathrm{~h}$ (Oshino and Sato, 1972; Toyama et al., 2007). It is important to note that in the present study the effect of LE-CLA on milk fat production was not apparent until after $3 \mathrm{~d}$ of supplementation with a continuing decline in milk fat for the next few days. Furthermore, Erasmus et al. (2004) conducted 2 studies with lactating goats involving different doses of a rumen-protected CLA supplement, but unfortunately details in their preliminary report are inadequate to allow for comparisons. Nevertheless, in their second study, they observed a significant reduction in milk fat content at their greatest dose and suggested that on a BW basis, goats may require a greater dose of CLA to achieve milk fat depression comparable to cows.

Our results also suggest a greater dose of CLA is required for a comparable inhibition of milk fat synthesis in goats. In lactating sheep, $25 \mathrm{~g} / \mathrm{d}$ of LE-CLA provided about $2.4 \mathrm{~g} / \mathrm{d}$ of trans-10, cis-12 CLA and gave a $23 \%$ and 16 to $20 \%$ reduction in the content and yield of milk fat, respectively (Lock et al., 2006; Sinclair et al., 2007); accounting for the portion metabolized in the rumen and using the dose-response relationships summarized by de Veth et al. (2004), this was comparable to a 23 and $21 \%$ reduction in milk fat content and milk fat yield in cows when the dose was expressed on the basis of metabolic BW. In the present study, we observed that a similar amount of trans-10, cis-12 CLA supplied as a lipid-encapsulated supplement to lactating goats gave a reduction of only 5 and $8 \%$ in milk fat content and yield, respectively. Values comparable to sheep and cows were only observed in lactating goats when the amount of CLA supplement was doubled; the $60 \mathrm{~g} / \mathrm{d}$ of LE-CLA supplement to lactating goats gave a 18 and $21 \%$ reduction in content and yield of milk fat, respectively (Table 2). Consistent with this difference in milk fat response, the transfer efficiency of trans-10, cis-12 CLA from the lipid-encapsulated supplement to milk fat was somewhat less in goats (1.80 to $1.89 \%$ ) as observed for the supplement administrated to lactating sheep (2.5 to 3.8\%; Lock et al., 2006; Sinclair et al., 2007).

The reduced effectiveness of dietary supplements of CLA in goats as compared with sheep and cows could be due to differences in processes occurring in the digestive tract or in postabsorptive use of CLA. Possibilities related to digestive processes would include a greater metabolism of the CLA supplement in the rumen or a lower bioavailability of the CLA supplement in the small intestine of goats, or both. Differences in postabsorptive use could include a greater use of CLA by nonmammary tissues or a reduced uptake and availability in the mammary epithelial cell. The present study did not directly examine these possibilities, but indirect evidence provides some insight. Although we found that the transfer efficiency of trans-10, cis-12 CLA provided as a dietary supplement was only about $50 \%$ of the value observed in cows and sheep, de Andrade and Schmidely (2006) observed a 17.8\% transfer efficiency of trans-10, cis-12 CLA provided by duodenal infusion in goats, which is comparable to the average $21.7 \%$ found in a summary of multiple doses in 7 studies with lactating cows (de Veth et al., 2004). That suggests that the basis may predominantly relate to a more extensive biohydrogenation of the CLA supplement in the rumen of goats, whereas bioavailability of CLA in the small intestine and the uptake of CLA by the mammary gland are similar among ruminant species. We examined this further by considering the observed reduction in milk fat in relation to the content of trans-10, cis-12 CLA in milk fat. Using the doseresponse equation for dairy cows developed by de Veth et al. (2004), the incremental increase in the concentration of trans-10, cis-12 CLA in milk fat observed in the present study for the CLA-1 and CLA-2 treatments (Table 3) would correspond (95\% prediction interval) to a predicted decrease in milk fat yield of 6 to $25 \%$ and 23 to $42 \%$, respectively; the observed reduction was 8 and $21 \%$ for the CLA-1 and CLA-2 treatments, respectively. Additional investigations are required to more 
fully explore the basis for the lower response in milk fat synthesis observed for goats.

Overall, the present study provides the first evidence that feeding of lipid-encapsulated supplements containing trans-10, cis-12 CLA was effective in reducing milk fat synthesis in lactating goats. Similar to other species, CLA effects involved a reduction in milk fatty acids of all chain lengths, although those arising from de novo synthesis were most dramatically reduced. As a consequence, the CLA supplementation of lactating goats resulted in a shift in milk fat composition to a greater proportion of unsaturated, longer chain fatty acids. Especially noteworthy, dose-response comparisons suggest that goats are less responsive in the magnitude of milk fat depression as compared with dairy cows and sheep.

\section{ACKNOWLEDGMENTS}

We acknowledge the support of E. Loetz and J. Hayes for animal care at Langston University and D. Dwyer and J. L. Capper for fatty acid analysis at Cornell University.

\section{REFERENCES}

AOAC. 2000. Official Methods of Analysis. 17th ed. Assoc. Off. Anal. Chem., Arlington, VA.

Bauman, D. E., and J. M. Griinari. 2003. Nutritional regulation of milk fat synthesis. Annu. Rev. Nutr. 23:203-227.

Bauman, D. E., J. W. Perfield II, K. J. Harvatine, and L. H. Baumgard. 2008. Regulation of fat synthesis by CLA: Lactation and the ruminant model. J. Nutr. 138:403-409.

Baumgard, L. H., B. A. Corl, D. A. Dwyer, and D. E. Bauman. 2002. Effects of conjugated linoleic acids (CLA) on tissue response to homeostatic signals and plasma variables associated with lipid metabolism in lactating dairy cows. J. Anim. Sci. 80:12851293.

Baumgard, L. H., B. A. Corl, D. A. Dwyer, A. Saebo, and D. E. Bauman. 2000. Identification of the conjugated linoleic acid isomer that inhibits milk fat synthesis. Am. J. Physiol. Regul. Integr. Comp. Physiol. 278:R179-R184.

Bernal-Santos, G., J. W. Perfield II, D. M. Barbano, D. E. Bauman, and T. R. Overton. 2003. Production responses of dairy cows to dietary supplementation with conjugated linoleic acid (CLA) during the transition period and early lactation. J. Dairy Sci. 86:3218-3228

Castañeda-Gutiérrez, E., B. C. Benefield, M. J. de Veth, N. R. Santos, R. O. Gilbert, W. R. Butler, and D. E. Bauman. 2007. Evaluation of the mechanism of action of conjugated linoleic acid isomers on reproduction in dairy cows. J. Dairy Sci. 90:4253-4264.

Chouinard, P. Y., L. Corneau, D. M. Barbano, L. E. Metzger, and D. E. Bauman. 1999. Conjugated linoleic acids alter milk fatty acid composition and inhibit milk fat secretion in dairy cows. J. Nutr. 129:1579-1584

Christie, W. W. 1982. A simple procedure for rapid transmethylation of glycerolipids and cholesteryl esters. J. Lipid Res. 23:10721075 .

Craig, M. C., C. M. Nepokroeff, M. R. Lakshmanan, and J. W. Porter. 1972. Effect of dietary change on the rates of synthesis and degradation of rat liver fatty acid synthetase. Arch. Biochem. Biophys. 152:619-630. de Andrade, P. V. D., and P. Schmidely. 2006. Effect of duodenal infusion of trans 10 , cis 12 -CLA on milk performance and milk fatty acid profile in dairy goats fed high or low concentrate diet in combination with rolled canola seed. Reprod. Nutr. Dev. 46:31-48.

de Veth, M. J., E. Castañeda-Gutiérrez, D. A. Dwyer, A. M. Pfeiffer, D. E. Putman, and D. E. Bauman. 2006. Response to conjugated linoleic acid in dairy cows differing in energy and protein status. J. Dairy Sci. 89:4620-4631.

de Veth, M. J., J. M. Griinari, A. M. Pfeiffer, and D. E. Bauman. 2004. Effect of CLA on milk fat synthesis in dairy cows: Comparison of inhibition by methyl esters and free fatty acids, and relationships among studies. Lipids 39:365-372.

Erasmus, L. J., Z. Bester, T. Fouric, R. J. Coertze, and L. Hall. 2004 Effect of level of rumen protected CLA supplementation on milk yield and composition in Saanen goats. S. Afr. J. Anim. Sci. 34(Suppl. 1):42-45.

Griinari, J. M., and D. E. Bauman. 2006. Milk fat depression Concepts, mechanisms and management. Pages 389-417 in Ruminant Physiology: Digestion, Metabolism and Impact of Nutrition on Gene Expression, Immunology and Stress. K. Sejrsen, T. Hvelplund, and M. O. Nielson, ed. Wageningen Academic Publishers, Wageningen, the Netherlands.

Hara, A., and N. S. Radin. 1978. Lipid extraction of tissues with a low-toxicity solvent. Anal. Biochem. 90:420-426.

Harvatine, K. J., and D. E. Bauman. 2006. SREBP1 and thyroid hormone responsive spot 14 (S14) are involved in the regulation of bovine mammary lipid synthesis during diet-induced milk fat depression and treatment with CLA. J. Nutr. 136:2468-2474.

Kelsey, J. A., B. A. Corl, R. J. Collier, and D. E. Bauman. 2003. The effect of breed, parity, and stage of lactation on conjugated linoleic acid (CLA) in milk fat from dairy cows. J. Dairy Sci 86:2588-2597.

Lock, A. L., B. M. Teles, J. W. Perfield II, D. E. Bauman, and L. A. Sinclair. 2006. A conjugated linoleic acid supplement containing trans-10, cis-12 reduces milk fat synthesis in lactating sheep. J. Dairy Sci. 89:1525-1532.

Loor, J. J., and J. H. Herbein. 2003. Reduced fatty acid synthesis and desaturation due to exogenous trans 10, cis12-CLA in cows fed oleic or linoleic oil. J. Dairy Sci. 85:1354-1369.

Mackle, T. R., J. K. Kay, M. J. Auldist, A. K. H. MacGibbon, B. A. Philpott, L. H. Baumgard, and D. E. Bauman. 2003. Effects of abomasal infusion of conjugated linoleic acid on milk fat concentration and yield from pasture-fed dairy cows. J. Dairy Sci. 86:644-652.

Odens, L. J., R. Burgos, M. Innocenti, M. J. VanBaale, and L. H. Baumgard. 2007. Effects of varying doses of supplemental conjugated linoleic acid on production and energetic variables during the transition period. J. Dairy Sci. 90:293-305.

Oshino, N., and R. Sato. 1972. The dietary control of the microsomal stearyl CoA desaturation enzyme system in rat liver. Arch. Biochem. Biophys. 149:369-377.

Perfield, J. W. II, A. L. Lock, A. M. Pfeiffer, and D. E. Bauman. 2004. Effects of amide-protected and lipid-encapsulated conjugated linoleic acid (CLA) supplements on milk fat synthesis. J. Dairy Sci. 87:3010-3016.

Sanz Sampelayo, M. R., Y. Chilliard, P. Schmidely, and J. Boza. 2007. Influence of type of diet on the fat constituents of goat and sheep milk. Small Rumin. Res. 68:42-63.

Schmidely, P., and P. Morand-Fehr. 2004. Effects of intravenous infusion of trans-10, cis-12 or cis-9, trans-11 conjugated linoleic acid (CLA) on milk fat synthesis and composition in dairy goats during mid-lactation. S. Afr. J. Anim. Sci. 34(Suppl.1):195-197.

Shingfield, K. J., and J. M. Griinari. 2007. Role of biohydrogenation intermediates in milk fat depression. Eur. J. Lipid Sci. Technol. 1009:799-816.

Sinclair, L. A., A. L. Lock, R. Early, and D. E. Bauman. 2007. Effects of trans-10, cis-12 conjugated linoleic acid on ovine milk fat synthesis and cheese properties. J. Dairy Sci. 90:3326-3335.

Toyama, T., N. Kudo, A. Mitsumoto, Y. Hibino, T. Tsuda, and Y. Kawashima. 2007. Stearoyl-CoA desaturase activity is elevated 
by the suppression of its degradation by clofibric acid in the liver of rats. J. Pharmacol. Sci. 103:383-390.

Villaquiran, M., T. Gipson, R. Merkel, A. Goetsch, and T. Sahlu. 2005. Body condition scoring for improved management. Pages 111117 in Proc. 20th Annual Goat Field Day. Langston University, Langston, OK.

Volpe, J. J., and P. R. Vagelos. 1973. Saturated fatty acid biosynthesis and its regulation. Annu. Rev. Biochem. 42:21-60.
Weerasinghe, W. M. P. B., R. G. Wilkinson, A. L. Lock, M. J. de Veth, D. E. Bauman, and L. A. Sinclair. 2007. Effects of supplementation with conjugated linoleic acid (CLA) and altered dietary protein level on the performance of dairy ewes. 5th Euro Fed Lipid Congress and 24th Symp. Nordic Lipid forum, Gothenburg, Sweden. Page 199 in Book of Abstracts. Euro Fed Lipid, Frankfort, Germany. 